Check for updates

Cite this: RSC Adv., 2019, 9, 31196

Received 8th August 2019

Accepted 25th September 2019

DOI: $10.1039 / c 9 r a 06174 f$

rsc.li/rsc-advances

\section{A simple sensor based on 1,8-naphthalimide with large Stokes shift for detection of hypochlorous acid in living cells $\uparrow$}

\author{
Chunpeng Jiao, abcd Yuanyuan Liu, abcd Wenjuan Lu, abcd Pingping Zhang, (DD abcd \\ Xia $\mathrm{Ma}^{\text {ae }}$ and Yanfeng Wang (iD *abcd
}

\begin{abstract}
Hypochlorous acid $(\mathrm{HOCl})$, one of the most reactive and deleterious reactive oxygen species (ROS), plays a vital role in many pathological and physiological processes. However, as a result of the highly reactive and diffusible nature of $\mathrm{HOCl}$, its uncontrolled production may lead to an adverse effect on host physiology. Because of its biological importance, many efforts have been focused on developing selective fluorescent probes to image $\mathrm{HOCl}$. However, it is still challenging to design a fluorescent probe with exclusive selectivity towards $\mathrm{HOCl}$. In this study, a novel fluorescent probe for $\mathrm{HOCl}$, Probe 1 was rationally designed based on 1,8-naphthalimide. As the concentration of $\mathrm{HOCl}$ increased, the fluorescence intensity of the probe gradually decreased, and the solution color changed from yellowgreen to colorless, indicating this is a "naked-eye sensor". Probe 1 has a large Stokes shift (120 nm), which can effectively avoid fluorescence self-absorption. In addition, Probe 1 shows excellent selectivity to $\mathrm{HOCl}$ among different ions including common ROS, high sensitivity, fast response (<2 min), high fluorescence quantum yield $(\Phi=0.93)$ and low detection limit $(0.237 \mu \mathrm{M})$. Finally, the imaging results in HeLa cells showed that the probe could be used for the detection of exogenous and endogenous $\mathrm{HOCl}$, and proved the potential of the probe as a biosensor for the detection of $\mathrm{HOCl}$.
\end{abstract}

\section{Introduction}

Reactive oxygen species (ROS), such as hypochlorous acid (HOCl), superoxide $\left(\mathrm{O}_{2}{ }^{-}\right)$, hydroxyl radical $\left({ }^{\circ} \mathrm{OH}\right)$, hydrogen peroxide $\left(\mathrm{H}_{2} \mathrm{O}_{2}\right)$ and peroxynitrite $\left(\mathrm{ONOO}^{-}\right)$, are the natural byproducts of normal metabolism and play vital roles in various physiological processes. ${ }^{1-5}$ Among them, hypochlorous acid can partially ionize hypochlorite at slightly acidic and physiological pH. Endogenous hypochlorite is mainly produced by the reaction of $\mathrm{H}_{2} \mathrm{O}_{2}$ and $\mathrm{Cl}^{-}$under the catalysis of myeloperoxidase (MPO), which is a major antimicrobial and oxidant agent for the immune system. ${ }^{6-8}$ However, abnormal levels of $\mathrm{HOCl}$ may cause tissue damage and a variety of human diseases such as cardiovascular diseases, cystic fibrosis cancers, atherosclerosis, arthritis and neuron degeneration..$^{9-14}$ Accordingly, it is urgent

${ }^{a}$ School of Medicine and Life Sciences, University of Jinan-Shandong Academy of Medical Sciences, Jinan 250200, Shandong, China. E-mail: wyfshiwoya@126.com

${ }^{b}$ Institute of MateriaMedica, Shandong Academy of Medical Sciences, Jinan 250062, Shandong, China

${ }^{c}$ Key Laboratory for Biotech-Drugs Ministry of Health, Jinan 250062, Shandong, China ${ }^{d}$ Key Laboratory for Rare \& Uncommon Diseases of Shandong Province, Jinan 250062, Shandong, China

${ }^{e}$ Shandong Institute of Medicine and Health Information, Shandong First Medical University, Shandong Academy of Medical Sciences, Jinan 250062, Shandong, China $\uparrow$ Electronic supplementary information (ESI) available. See DOI: 10.1039/c9ra06174f to develop new analytical methods for the sensitive and accurate detection and monitoring of HOCl.

Recently, in order to carry out this research, many sensitive and selective analytical methods have been developed such as colorimetric, luminescent, radiolysis, electrochemical and optical imaging methods. ${ }^{15-20}$ Notably, fluorescent methods have advantages of high sensitivity, good selectivity, strong specificity and fast response time, which is widely used in biological imaging. ${ }^{21-25}$ In addition, in order to avoid serious selfabsorption of fluorescence, probe molecules will be designed with large stokes shift, and when excited at the maximum absorption peak, the interference of excited light on fluorescence signal will be greatly reduced.

A variety of mechanisms for detecting hypochlorous acid have been discovered so far, such as Photoinduced Electron Transfer (PET), ${ }^{\mathbf{2 6}, 27}$ Intramolecular Charge Transfer (ICT), ${ }^{28}$ fluorescence resonance energy transfer (FRET). ${ }^{29}$ The selection of probe molecules for fluorophore is also diverse, such as rhodamine dye ${ }^{30-32}$ boron-dipyrromethene (BODIPY), ${ }^{33-35}$ 1,8naphthalimide-derived, ${ }^{36}$ coumarin, ${ }^{37}$ anthocyanins ${ }^{38,39}$ and so on.

In this work, we designed and synthesized a small-molecule fluorescent probe (Probe 1), which connected the electron donor group benzothizole to the naphthalimide backbone through covalent bond. The electron donor capacity of benzothizole increased the fluorescence quantum yield of the probe 
molecule. ${ }^{40}$ Upon reaction to $\mathrm{HOCl}$, the fluorescence intensity of Probe 1 decreased and significant change with the solution colour (yellow-green to colourless), which could be used as a fluorometric or colorimetric indicator for HOCl. This molecular probe features a thioether group (MeS) fluorescent modulator that is integrated into naphthalimide. The probe is found to be selective for the reversible monitoring of $\mathrm{HOCl}$ and glutathione (GSH) redox cycles. The fluorescent intensity of Probe 1 showed a good linear relationship with the concentration of $\mathrm{HOCl}$ at $0-15$ eq., a low limit of detection $(0.237 \mu \mathrm{M})$, and could be applied to monitor fluctuations in basal HOCl levels and endogenous/exogenous HOCl levels in HeLa cells.

\section{Experimental}

\section{Material and instruments}

All solvents and chemicals were purchased from commercial suppliers and were used without further purification unless otherwise stated. Column chromatography was conducted on silica gel (200-300 mesh) and thin layer chromatography (TCL) was performed using silica gel 60 F254 (Qingdao Ocean Chemicals, Qingdao, China). ${ }^{1} \mathrm{H}$ NMR and ${ }^{13} \mathrm{C}$ NMR spectra were recorded on a Bruker Avance $300 \mathrm{MHz}$ spectrometer. High resolution mass spectra (HRMS) were recorded on an Agilent 1290LC-6540 Accurate Mass Q-TOF by using electrospray ionization (ESI). Fluorescent spectra were measured by using TU1901 (Beijing Purkinje General Instrument Co., Ltd.) and F280 (Tianjin Gangdong Technology Co., Ltd.). The cytotoxicity assay measures the absorption wavelength at $490 \mathrm{~nm}$ by means of an enzyme labeling device (Synergy HT). Fluorescence imaging of $\mathrm{HOCl}$ in live HeLa cells was measured under an Olympus FV1000 confocal fluorescence microscope.

\section{Preparation of ROS and RNS}

Various ROS and RNS, including $\mathrm{NO}_{2}{ }^{-}, \mathrm{NO}_{3}{ }^{-}, \mathrm{HOCl}, \mathrm{H}_{2} \mathrm{O}_{2}, \mathrm{NO}$, $\cdot \mathrm{OH}, \mathrm{ONOO}^{-}, \mathrm{O}_{2}$ and $t$ - $\mathrm{BuOOH}$, were prepared according to the following methods. The source of $\mathrm{NO}_{2}{ }^{-}$and $\mathrm{NO}_{3}{ }^{-}$was $\mathrm{NaNO}_{2}$ and $\mathrm{NaNO}_{3}$, respectively. The concentration of hypochlorite was determined at the absorption wavelength of $292 \mathrm{~nm}(\varepsilon=$ $350 \mathrm{M}^{-1} \mathrm{~cm}^{-1}$ ) with commercial NaClO solution as the source of $\mathrm{HOCl}$. The concentration of $\mathrm{H}_{2} \mathrm{O}_{2}$ was determined from the absorption at $240 \mathrm{~nm}\left(\varepsilon=43.6 \mathrm{M}^{-1} \mathrm{~cm}^{-1}\right)$. NO is made from sodium nitroprusside. Hydroxyl radicals were generated by Fenton reaction, and hydrogen peroxide $\left(\mathrm{H}_{2} \mathrm{O}_{2}, 10\right.$ eq.) was added to $\mathrm{FeSO}_{4}$ in deionized water. $\mathrm{ONOO}^{-}, \mathrm{O}_{2}$ and $t-\mathrm{BuOOH}$ were prepared according to the reported method. ${ }^{41}$

\section{Synthesis}

6-(Methylthio)benzo[de]isochromene-1,3-dione (2). 6-Bromobenzo[de]isochromene-1,3-dione $(0.552 \mathrm{~g}, 2 \mathrm{mmol})$ was dissolved in $10 \mathrm{~mL}$ of DMF. $\mathrm{K}_{2} \mathrm{CO}_{3}(0.276 \mathrm{~g}, 2 \mathrm{mmol})$ and $\mathrm{CH}_{3} \mathrm{SNa}$ $(0.280 \mathrm{~g}, 4 \mathrm{mmol})$ was added into the solution in sequence. The mixture was then heated to $80^{\circ} \mathrm{C}$ and reacted for $4 \mathrm{~h}$ under $\mathrm{N}_{2}$ atmosphere. After completion of the reaction, the mixture was poured into $100 \mathrm{~mL}$ ice-water and $10 \mathrm{~mL}$ hydrochloric acid (1 M) was added slowly to precipitate the yellow solid, then filtration.
The crude product was purified by column chromatography over silica gel using dichloromethane/petroleum ether $(4: 1 \mathrm{v} / \mathrm{v})$ as eluent to afford the compound (2) as pale yellow solid $(0.36 \mathrm{~g}$, yield $74 \%) .{ }^{1} \mathrm{H}$ NMR $\left(300 \mathrm{MHz}, \mathrm{CDCl}_{3}\right) \delta=8.58(\mathrm{dd}, J=7.3,1.0$, $1 \mathrm{H}), 8.53(\mathrm{dd}, J=8.5,1.0,1 \mathrm{H}), 8.44(\mathrm{~d}, J=8.0,1 \mathrm{H}), 7.74(\mathrm{dd}, J=$ 8.5, 7.4, $1 \mathrm{H}), 7.43(\mathrm{~d}, J=8.0,1 \mathrm{H}), 2.66(\mathrm{~s}, 3 \mathrm{H}) .{ }^{13} \mathrm{C}$ NMR $(75 \mathrm{MHz}$, $\left.\mathrm{CDCl}_{3}\right) \delta=160.5,148.8,133.6,132.9,131.0,130.2,129.1,126.9$, 121.2, 119.4, 114.4, 14.8. HRMS: $[\mathrm{M}+\mathrm{H}]^{+}$calcd for $\mathrm{C}_{13} \mathrm{H}_{8} \mathrm{O}_{3} \mathrm{~S}$ : 245.0272; found 245.0259.

2-(Benzo[d]thiazol-2-yl)-6-(methylthio)-1H-benzo[de]isoquinoline-1,3(2H)-dione (1). Compound $2(0.488 \mathrm{~g}, 2 \mathrm{mmol})$ was dissolved in $10 \mathrm{~mL}$ of DMF. $\left(\mathrm{CH}_{3} \mathrm{COO}\right)_{2} \mathrm{Zn}(0.044 \mathrm{~g}, 0.2 \mathrm{mmol})$ and benzo[ $d]$ oxazol-2-amine $(0.322 \mathrm{~g}, 2.4 \mathrm{mmol})$ was added into the solution in sequence. The mixture was then heated to $140^{\circ} \mathrm{C}$ reacted for $12 \mathrm{~h}$ under $\mathrm{N}_{2}$ atmosphere. After the reaction, the mixture was poured into ice-water to obtain the yellow solid. The solid was collected through filtration and wash with water three times. The crude product was purified by silica gel column chromatography (dichloromethane: petroleum ether $=1: 1$ ) to afford the compound (1) as pale green solid $(0.522 \mathrm{~g}$, yield $69 \%)$.

${ }^{1} \mathrm{H}$ NMR $\left(300 \mathrm{MHz}, \mathrm{CDCl}_{3}+\mathrm{CF}_{3} \mathrm{COOD}\right) \delta=8.92(\mathrm{~d}, J=6.8$, $1 \mathrm{H}), 8.82(\mathrm{~d}, J=8.4,1 \mathrm{H}), 8.76(\mathrm{~d}, J=8.2,1 \mathrm{H}), 8.25(\mathrm{~d}, J=8.2$, $1 \mathrm{H}), 8.14(\mathrm{~d}, J=7.9,1 \mathrm{H}), 8.01-7.93(\mathrm{~m}, 1 \mathrm{H}), 7.88(\mathrm{dd}, J=11.5$, $4.2,1 \mathrm{H}), 7.82(\mathrm{dd}, J=11.3,4.1,1 \mathrm{H}), 7.66(\mathrm{~d}, J=8.2,1 \mathrm{H}), 2.80(\mathrm{~s}$, $3 \mathrm{H}) .{ }^{13} \mathrm{C}$ NMR (75 MHz, $\left.\mathrm{CDCl}_{3}+\mathrm{CF}_{3} \mathrm{COOD}\right) \delta=163.3,163.2$, $160.5,153.9,135.2,134.7,134.6,133.4,130.5,129.0,128.7$, 127.7, 127.5, 122.1, 121.6, 119.1, 117.7, 113.8, 14.6. HRMS: [M + $\mathrm{H}]^{+}$calcd for $\mathrm{C}_{20} \mathrm{H}_{12} \mathrm{~N}_{2} \mathrm{O}_{2} \mathrm{~S}_{2}: 377.0418$; found 377.0400.

\section{Determination of the detection limit}

The limit of detection (LOD) for HOCl was calculated by fluorescence spectrometry. The LOD was obtained by the following equation: $\mathrm{LOD}=3 \sigma / k$ ( $\sigma$ is the standard deviation of the blank measurement, and $k$ was the slope of the fluorescence intensity graph with sample concentration). In order to reduce the error, the fluorescence of the Probe 1 was calculated 20 times to obtain an $\mathrm{S} / \mathrm{N}$ ratio, and the standard deviation of the blank measurement was obtained.

\section{Cytotoxicity assay}

The methyl thiazolyl tetrazolium (MTT) assay was used to measure the cytotoxicity of Probe 1. HeLa cells were seeded into a 96-well cell-culture plate. Various concentrations $(5,10,20,30$ $\mu \mathrm{M})$ of Probe 1 were added to the wells. HeLa cells were incubated in culture media (DMEM) in an atmosphere of $5 \% \mathrm{CO}_{2}$ and $95 \%$ air at $37^{\circ} \mathrm{C}$. After that, $10 \mathrm{~mL}$ MTT $\left(5 \mathrm{mg} \mathrm{mL}^{-1}\right)$ was added to each well and incubated at $37^{\circ} \mathrm{C}$ under $5 \% \mathrm{CO}_{2}$ for $4 \mathrm{~h}$. The supernatant from the orifice plate was removed, 150 microliters of DMSO were added, and shaken with a shaker. The absorption wavelength was measured by an enzyme labelling apparatus (Synergy HT) at $490 \mathrm{~nm}$.

\section{Cell viability $(\%)=($ mean of absorbance value of treatment} group)/(mean of absorbance value of control group). 


\section{Cell culture and fluorescent imaging}

HeLa cells were cultured in an atmosphere of $5 \% \mathrm{CO}_{2}$ and $95 \%$ air in Dulbecco's modified Eagle's medium (DMEM) at $37{ }^{\circ} \mathrm{C}$ for $24 \mathrm{~h}$, and then some of the cells were incubated with LPS (lipopolysaccharide, $1 \mu \mathrm{g} \mathrm{mL}{ }^{-1}$ ) for $6 \mathrm{~h}$, and further incubated with PMA (phorbol 12-myristate 13-acetate, $1 \mu \mathrm{g} \mathrm{mL} \mathrm{m}^{-1}$ ) for $30 \mathrm{~min}$, and then with Probe $1\left(10^{-5} \mathrm{M}\right)$ for another $30 \mathrm{~min}$. Cells were imaged using confocal fluorescence microscope (Olympus FLUOVIEW FV1000).

\section{Results and discussion}

Probe 1 was synthesized by reflux reaction of 6-(methylthio) benzo[de]-isochromene-1,3-dione and benzo[ $d]$ oxazol-2aminein in DMF under nitrogen protection and catalyzed by $\left(\mathrm{CH}_{3} \mathrm{COO}\right)_{2} \mathrm{Zn}$ with a yield of $69 \%$ (Scheme 1$)$. The product and intermediate were characterized by ${ }^{1} \mathrm{H}$ NMR, ${ }^{13} \mathrm{C}$ NMR and HRMS (Fig. S1-S5†).

\section{Absorption and fluorescence spectra of Probe 1 titrated with HOCl}

To explore the spectral properties of Probe 1, the UV-vis absorption spectra and fluorescence emission spectra of Probe $1\left(10^{-5} \mathrm{M}\right)$ were investigated in DMSO-PBS ( $1: 9, \mathrm{v} / \mathrm{v} ; \mathrm{pH}=7.2)$ solution. First, we performed a selective test on the probe between $\mathrm{HOCl}$ and other influencing factors (all 10 eq.; $\mathrm{F}^{-}, \mathrm{Cl}^{-}, \mathrm{Br}^{-}, \mathrm{NO}_{3}{ }^{-}, \mathrm{NO}_{2}{ }^{-}$, $\mathrm{N}_{3}{ }^{-}, \mathrm{SO}_{4}{ }^{2-}, \mathrm{SO}_{3}{ }^{2-}, \mathrm{HCO}_{3}{ }^{-}, \mathrm{CO}_{3}{ }^{2-}, \mathrm{PO}_{4}{ }^{3-}, \mathrm{H}_{2} \mathrm{PO}_{4}{ }^{-}, \mathrm{HPO}_{4}{ }^{2-}$, $\mathrm{CH}_{3} \mathrm{COO}^{-}, \mathrm{Ag}^{+}, \mathrm{Al}^{3+}, \mathrm{Ca}^{2+}, \mathrm{Cr}^{3+}, \mathrm{Co}^{2+}, \mathrm{Fe}^{2+}, \mathrm{Fe}^{3+}, \mathrm{Mn}^{2+}, \mathrm{Ni}^{2+}, \mathrm{Pb}^{2+}$, $\mathrm{Zn}^{2+}, \mathrm{Cu}^{2+}, \mathrm{Hg}^{2+}, \mathrm{Cd}^{2+}, \mathrm{H}_{2} \mathrm{O}_{2}, \mathrm{NO}, \mathrm{ONOO}^{-}, \mathrm{O}_{2},{ }^{\circ} \mathrm{OH}, \mathrm{T}-\mathrm{Buoo}^{-}$). As shown in Fig. 1a, other ions or molecules such as showed no obvious affect on the UV absorption spectrum of the Probe 1 except for HOCl. These results suggested that Probe 1 exhibits good selectivity toward $\mathrm{HOCl}$ in physiological conditions. After reaction with $\mathrm{HOCl}$ of Probe 1, a new absorption peak appeared at $350 \mathrm{~nm}$, which gradually enhanced with the increase of $\mathrm{HOCl}$ concentration accompanied by decreasing of original absorption peak at $400 \mathrm{~nm}$ until disappear, and formed an isosbestic point at $375 \mathrm{~nm}$ (Fig. 1b). The absorption ratio of Probe 1 at $350 \mathrm{~nm}$ and $400 \mathrm{~nm}\left(A_{350} / A_{400}\right)$ has a good linear relationship with $\mathrm{HOCl}$ concentration (0-10 eq.) (Fig. 1c). The absorption spectrum has undergone a significant blue shift compared to the original state. That is because the electron donating ability of the $\mathrm{S}$ element is inhibited after the thioether oxidized to the sulfoxide by $\mathrm{HOCl}$, and the effect of intramolecular charge transfer (ICT) is prevented. The colour of Probe 1 solution changed from yellow-green to colourless after adding HOCl (Fig. 1g), which could be used as a "naked-eye sensor" and a highly accurate ratio determination.

After studying the UV absorption spectrum, we examined the specificity of the Probe 1 for the fluorescence response of $\mathrm{HOCl}$. All fluorescence instrument parameter settings are as follows: excitation wavelength $400 \mathrm{~nm}$, slit 5/5. In the DMSO : PBS buffer (1: 9 , v: v) containing the Probe $1\left(10^{-5} \mathrm{M}\right)$, various ions and molecular including $\mathrm{H}_{2} \mathrm{O}_{2}, \mathrm{NO}, \mathrm{ONOO}^{-}, \mathrm{O}_{2},{ }^{\circ} \mathrm{OH}$ and T-Buoo was added separately, only HOCl led to a strong decrease of the fluorescent intensity at $520 \mathrm{~nm}$. No obvious changes were observed in the case of other ions and molecular (Fig. 1d). The
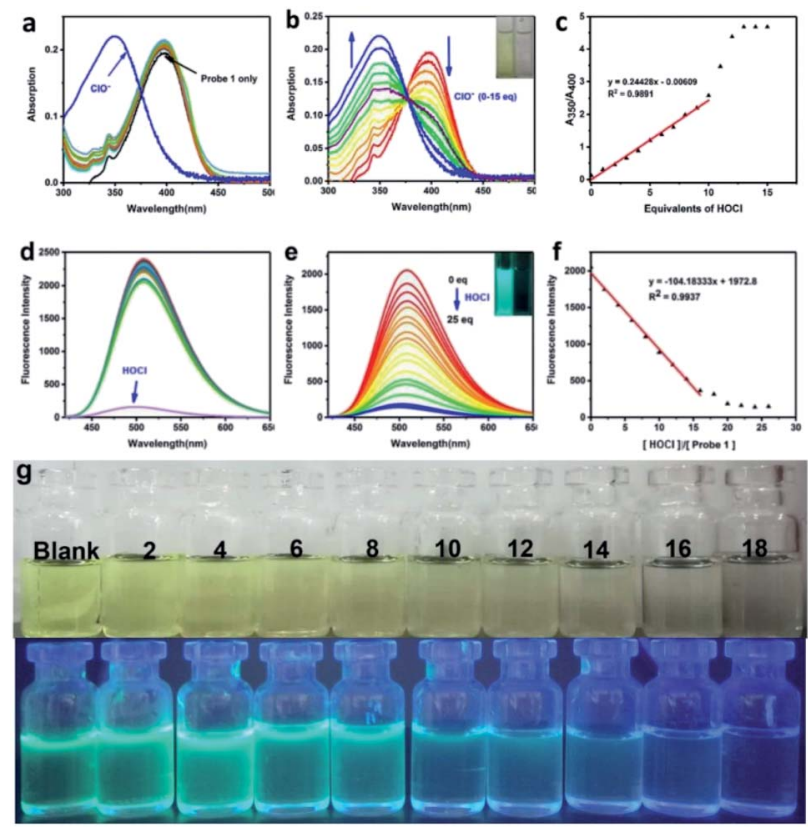

Fig. 1 In the UV absorption experiment and fluorescence spectrum experiment, Probe 1 concentration was $10^{-5} \mathrm{M}$ and the solution was DMSO-PBS (1: 9, v/v, pH = 7.20) solution. (a) UV-vis spectra of Probe 1 and UV-vis spectra with different influence factors added (all 10 eq.; $\mathrm{F}^{-}, \mathrm{Cl}^{-}, \mathrm{Br}^{-}, \mathrm{NO}_{3}{ }^{-}, \mathrm{NO}_{2}{ }^{-}, \mathrm{N}_{3}^{-}, \mathrm{SO}_{4}{ }^{2-}, \mathrm{SO}_{3}{ }^{2-}, \mathrm{HCO}_{3}{ }^{-}, \mathrm{CO}_{3}{ }^{2-}, \mathrm{PO}_{4}{ }^{3-}$, $\mathrm{H}_{2} \mathrm{PO}_{4}{ }^{-}, \mathrm{HPO}_{4}^{2-}, \mathrm{CH}_{3} \mathrm{COO}^{-}, \mathrm{Ag}^{+}, \mathrm{Al}^{3+}, \mathrm{Ca}^{2+}, \mathrm{Cr}^{3+}, \mathrm{Co}^{2+}, \mathrm{Fe}^{2+}, \mathrm{Fe}^{3+}$, $\mathrm{Mn}^{2+}, \mathrm{Ni}^{2+}, \mathrm{Pb}^{2+}, \mathrm{Zn}^{2+}, \mathrm{Cu}^{2+}, \mathrm{Hg}^{2+}, \mathrm{Cd}^{2+}, \mathrm{H}_{2} \mathrm{O}_{2}, \mathrm{HOCl}, \mathrm{NO}, \mathrm{ONOO}^{-}$, $\mathrm{O}_{2}, \mathrm{OH}, \mathrm{T}-\mathrm{Buoo}^{-}$). (b) UV-vis spectra of Probe 1 with the presence of $\mathrm{HOCl}(0-15$ eq.). Inset: the photo of Probe 1 (left) and Probe $1+\mathrm{HOCl}$ (15 eq.) (right). (c) Linearity of the ratio $A_{350} / A_{400}$ with the presence of $\mathrm{HOCl}(0-15$ eq.) of Probe 1. (d) Fluorescence spectrum of Probe 1 and fluorescence spectrum after response to 15 eq. of $\mathrm{HOCl}$ and other influencing factors (all 10 eq.; $\mathrm{F}^{-}, \mathrm{Cl}^{-}, \mathrm{Br}^{-}, \mathrm{NO}_{3}^{-}, \mathrm{NO}_{2}^{-}, \mathrm{N}_{3}^{-}, \mathrm{SO}_{4}{ }^{2-}$, $\mathrm{SO}_{3}{ }^{2-}, \mathrm{HCO}_{3}-, \mathrm{CO}_{3}{ }^{2-}, \mathrm{PO}_{4}{ }^{3-}, \mathrm{H}_{2} \mathrm{PO}_{4}{ }^{-}, \mathrm{HPO}_{4}{ }^{2-}, \mathrm{CH}_{3} \mathrm{COO}^{-}, \mathrm{Ag}^{+}, \mathrm{Al}^{3+}$, $\mathrm{Ca}^{2+}, \mathrm{Cr}^{3+}, \mathrm{Co}^{2+}, \mathrm{Fe}^{2+}, \mathrm{Fe}^{3+}, \mathrm{Mn}^{2+}, \mathrm{Ni}^{2+}, \mathrm{Pb}^{2+}, \mathrm{Zn}^{2+}, \mathrm{Cu}^{2+}, \mathrm{Hg}^{2+}, \mathrm{Cd}^{2+}$, $\mathrm{H}_{2} \mathrm{O}_{2}, \mathrm{NO}, \mathrm{ONOO}^{-}, \mathrm{O}_{2},{ }^{\circ} \mathrm{OH}, \mathrm{T}-\mathrm{BuOO}^{-}$). (e) Fluorescence response of Probe 1 treated with different concentrations of $\mathrm{HOCl}(0-25$ eq.). Inset: the photo of Probe 1 (left) and Probe $1+\mathrm{HOCl}$ (15 eq.) (right). (f) The corresponding linear relationship between fluorescence emission intensity at $520 \mathrm{~nm}$ and $\mathrm{HOCl}\left(0-15\right.$ eq.) with Probe $1\left(\lambda_{\text {ex }}=400 \mathrm{~nm}\right.$, slit $=5 \mathrm{~nm}$ ). (g) Dependence of the color change of Probe 1 on the amount of $\mathrm{HOCl}(0-18$ eq.) added in DMSO-PBS $(1: 9, \mathrm{v} / \mathrm{v}, \mathrm{pH}=7.20)$.

fluorescence quantum yield $(\Phi=0.93)$ of Probe 1 solution without $\mathrm{HOCl}$ was calculated with 9,10-diphenylanthracene $\left(\Phi_{\mathrm{F}}\right.$ $=0.95$ in ethanol $)^{42}$ as the reference fluorescence standard substance. This can be attributed to the strong electrondonating ability of $\mathrm{S}$ atoms in methyl sulfide, which is

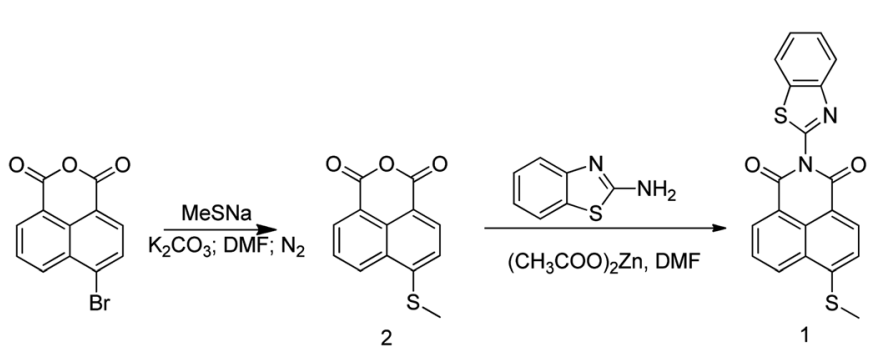

Scheme 1 Synthetic route of Probe 1. 
transferred to the naphthalene imide through ICT process, thus making the fluorescence quantum yield of Probe 1 extremely high. With the increase of HOCl concentration (0-25 eq.), the fluorescence intensity at the $520 \mathrm{~nm}$ gradually decreased and eventually almost completely quenched $(\Phi=0.04)$ (Fig. 1e). The fluorescence intensity of Probe 1 had a good linear relationship with the concentration of $\mathrm{HOCl}$ between 0 equivalent to 15 equivalents $\left(R^{2}=0.9937\right)$ (Fig. 1f). The LOD of Probe 1 for $\mathrm{HOCl}$ were found to be $0.237 \mu \mathrm{M}$. Under the UV light, only HOCl lead to the obvious colour changed of Probe 1 significantly (bluegreen to colourless). The results illustrate that Probe $\mathbf{1}$ has good selectivity and sensitivity to HOCl (Fig. 1d and S6 $\dagger^{\dagger}$ ).

\section{Time response and pH stability of Probe 1 to $\mathrm{HOCl}$}

The reaction of Probe 1 with $\mathrm{HOCl}$ was very quick, addition of HOCl (aq) (15 eq.) to the solution of Probe 1 caused a significant change in fluorescence intensity within $2 \mathrm{~min}$ (Fig. 2a). The time response has shown good results, then we evaluated the $\mathrm{pH}$ effect on the fluorescence of Probe 1 toward HOCl. It can be seen from Fig. $2 \mathrm{~b}$ that Probe $\mathbf{1}$ was very stable at $\mathrm{pH}$ value of 4.00-7.50 in the absence of $\mathrm{HOCl}$, when $\mathrm{pH}$ value was higher than 7.50, the fluorescence of it decreased slightly, but still maintained a relatively high. After the addition of $\mathrm{HOCl}$, the fluorescence of Probe 1 was almost completely quenched at any location with a $\mathrm{pH}$ value of $4.00-12.00$. The results indicated that Probe 1 has good stability in the range of $\mathrm{pH} 4.00-7.50$, and can be used for in vivo cell $\mathrm{HOCl}$ imaging studies under physiological pH conditions. The above results indicate that Probe 1 has certain advantages for $\mathrm{HOCl}$ detection compared to the reported fluorescent probe (Table S1†).
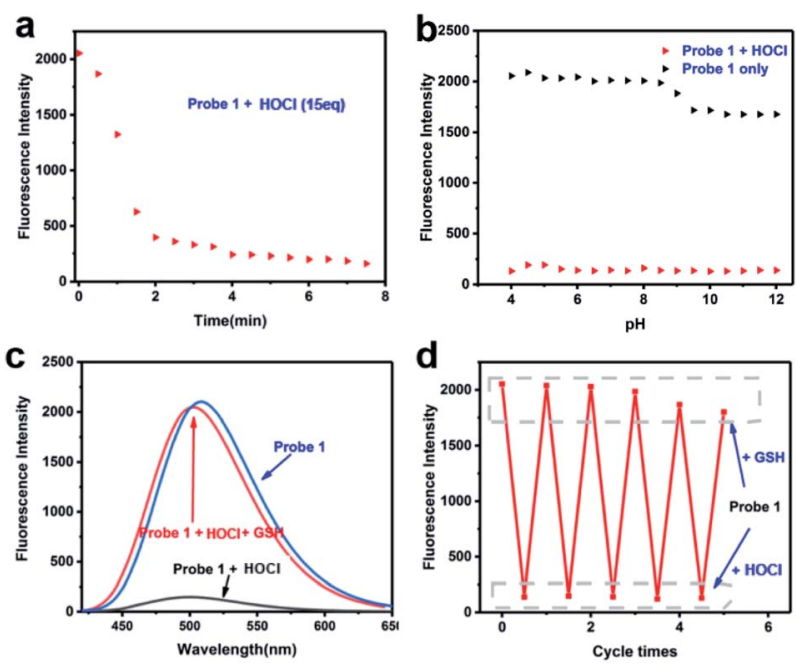

Fig. 2 (a) Time-dependent fluorescence intensity of Probe $1\left(10^{-5} \mathrm{M}\right)$ in DMSO-PBS (1: 9, v/v, $\mathrm{pH}=7.20)$ solution after the addition of $\mathrm{HOCl}$ (15 eq.). (b) The effect of $\mathrm{pH}$ at $520 \mathrm{~nm}$ on the fluorescence intensity of Probe $1\left(10^{-5} \mathrm{M}\right)$ before and after the addition of $\mathrm{HOCl}(15$ eq.). (c) Effect of $\mathrm{HOCl}(10$ eq.) and GSH (10 eq.) on fluorescence intensity of Probe $1\left(10^{-5} \mathrm{M}\right)$ in DMSO-PBS $(1: 9, \mathrm{v} / \mathrm{v}, \mathrm{pH}=7.20)$ solution. (d) Effect of $\mathrm{HOCl}(10$ eq.) and GSH (10 eq.) on fluorescence intensity of Probe $1\left(10^{-5} \mathrm{M}\right)$ to redox cycles in DMSO-PBS $(1: 9, \mathrm{v} / \mathrm{v}, \mathrm{pH}=7.20)$ solution. The time interval is 3 minutes.

\section{Cyclic response of Probe 1 to $\mathrm{HOCl}$ and GSH}

The $\mathrm{S}$ atoms of methyl sulfide in the probe can be oxidized by $\mathrm{HOCl}$, in order to investigate the stability of oxidation products, after added HOCl (15 eq.) into the probe solution for $2 \mathrm{~min}$, and then added different antioxidants (20 eq.) to determine which antioxidant could trigger the fluorescent switch on efficaciously (Fig. S7 $\dagger$ ). The results showed that GSH could restore fluorescence in the probe solution oxidized by $\mathrm{HOCl}$ (Fig. 2c), and the fluorescence recovery rate could be up to $95 \%$ within $1 \mathrm{~min}$. Other antioxidant including cysteine, $\mathrm{Fe}^{2+}$, vitamin $\mathrm{C}$, vitamin $\mathrm{E}$, histamine and so on could not restored the fluorescence of the reaction solution during $10 \mathrm{~min}$. Experiments with roundtrip addition of $\mathrm{HOCl}$ and GSH show that the reversible oxidation-reduction cycle could be repeated at least 3 times with a modest fluorescence decrement (Fig. 2d), because part of the thioether was oxidized to sulfone (Scheme 2 and Fig. S8†), which could not be reduced by GSH.

\section{Proposed reaction mechanism and NMR analysis}

As has been well shown in previous studies, ${ }^{43-45}$ the electron rich sulfide was easily oxidized to sulfoxide by $\mathrm{HOCl}$. To elucidate the detailed signal mechanism, the "turn-off" fluorescence sensing mechanism for Probe 1 toward $\mathrm{HOCl}$ was proposed in Scheme 2. The oxidation of Probe $\mathbf{1}$ by HOCl was demonstrated by HRMS, FT-IR and ${ }^{1} \mathrm{H}$ NMR. By HRMS analysis of the product of the reaction of Probe 1 with $\mathrm{HOCl}$ (20 eq.), We could get a new compound $\left(\mathrm{m} / \mathrm{z}: 393.0362\right.$, $[\mathrm{M}+\mathrm{H}]^{+}$calcd for $\mathrm{C}_{20} \mathrm{H}_{12} \mathrm{~N}_{2} \mathrm{O}_{3} \mathrm{~S}_{2}$ : 377.0418), which was the sulfoxide of Probe 1 oxidized by HOCl, then after adding the excess $\mathrm{HOCl}$ again, another new compound was found $\left(\mathrm{m} / \mathrm{z}: 409.0311,[\mathrm{M}+\mathrm{H}]^{+}\right.$calcd for $\mathrm{C}_{20} \mathrm{H}_{12} \mathrm{~N}_{2} \mathrm{O}_{4} \mathrm{~S}_{2}$ : 409.0317), which was the oxidized sulfone of Probe 1 (Fig. S8†). Meanwhile, the characteristic peaks of sulfoxide and sulfone were also obtained by FT-IR spectrum (Fig. S9 $\dagger$ ). The $\mathrm{S}=\mathrm{O}$ in the sulfoxide has a strong absorption peak in the range of 1070$1030 \mathrm{~cm}^{-1}$, and it is observed that a new absorption peak appears at $1059.38 \mathrm{~cm}^{-1}$ (Fig. S9b†). The spectrum of sulfone is strongly absorbed in the range of $1350-1300 \mathrm{~cm}^{-1}$ and $1160-1120 \mathrm{~cm}^{-1}$, and these bands are generated by the stretching vibration of symmetric and asymmetric $\mathrm{O}=\mathrm{S}=\mathrm{O}$, respectively. Two strong absorption peaks $1307.08 \mathrm{~cm}^{-1}$ and $1127.01 \mathrm{~cm}^{-1}$ can be found very well in Fig. S9c. $\dagger$ As the probe was gradually oxidized by $\mathrm{HOCl}$, the peak position of S-C bond changed from $774.32 \mathrm{~cm}^{-1}$

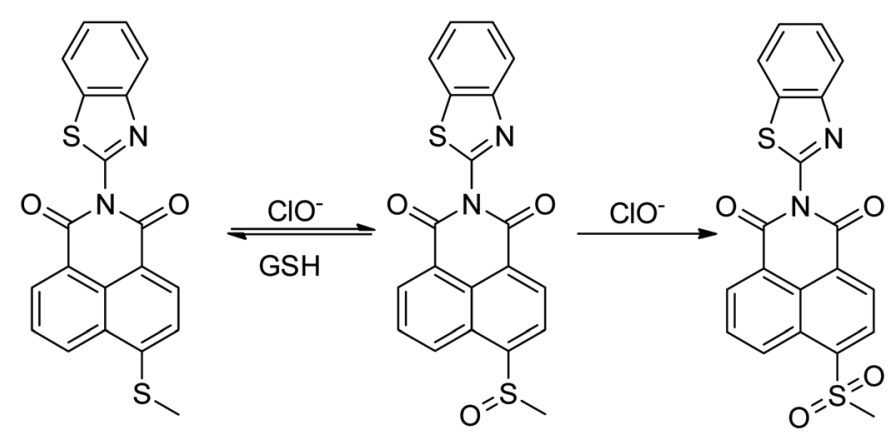

Scheme 2 Probe 1 reacted with hypochlorous acid and added GSH. 


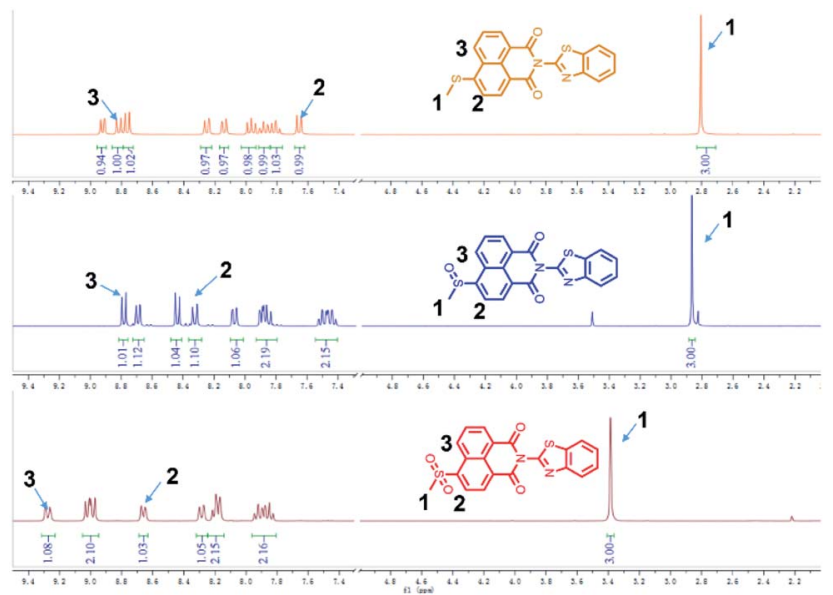

Fig. $3{ }^{1} \mathrm{H} \mathrm{NMR}$ before and after reaction of Probe 1 with $\mathrm{HOCl}\left(\mathrm{CDCl}_{3}\right)$.

to $760.71 \mathrm{~cm}^{-1}$ to $758.41 \mathrm{~cm}^{-1}$. Because the electron cloud density decreases after the sulfide is oxidized, the shielding effect is weakened, and the chemical potential of hydrogen on the methyl group moves to a lower field. We can clearly see the change in the degree of ${ }^{1} \mathrm{H}$ NMR on the methyl group after the reaction with $\mathrm{HOCl}(\mathrm{H} 1=2.80 ; 2.87 ; 3.39)$. At the same time the chemical displacement of the hydrogen at positions $\mathrm{H} 2$ and $\mathrm{H} 3$ is also affected by the shift to the lower field (Fig. 3).

\section{Cell imaging}

In order to explore the potential application in the biological field, MTT assay and cell imaging assay were performed on the probe. The stained HeLa cells cell were still survival viability than $80 \%$ after incubated for $24 \mathrm{~h}$ when used at higher probe concentrations $(40 \mu \mathrm{M})$, indicating Probe 1 has low toxicity and good biocompatibility for living cells (Fig. S10†). These results suggested that Probe $\mathbf{1}$ is a good fluorescence probe for cell imaging. Images were obtained using confocal fluorescence microscopy of cells, when HeLa cells were incubated with Probe $1\left(10^{-5} \mathrm{M}\right)$, the cells can observe a distinct bright green fluorescence (Fig. 4a). After the treatment with exogenous NaClO (15 eq.) ${ }^{46}$ the fluorescence in HeLa cells was obviously quenched

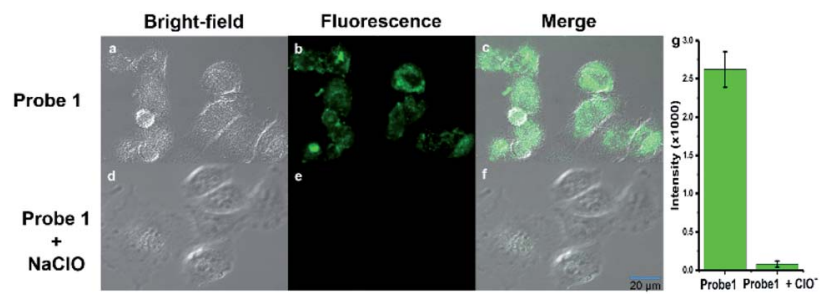

Fig. 4 Fluorescence images of HeLa cells. (a and d) Bright-field transmission images of HeLa cells, (b) HeLa cells pretreated with Probe $1\left(10^{-5} \mathrm{M}\right)$ for $30 \mathrm{~min}$, (e) pretreated with $\mathrm{NaClO}$ (15 eq.) for another 30 min after HeLa cells preincubation with Probe 1 for 30 min, and (c and f) overlay of (a) with (b), (d) with (e), respectively, (g) the bars represent the fluorescence intensity of the corresponding cells. The provided images of live HeLa cells macrophage are representative ones ( $n=6$ fields of cells).

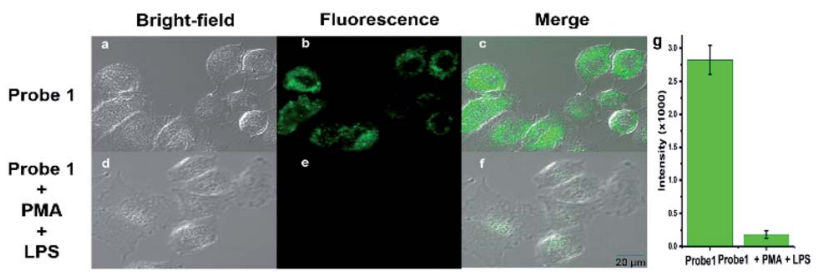

Fig. 5 Fluorescence images of HeLa cells. ( $a$ and d) Bright-field transmission images of HeLa cells, (b) HeLa cells pretreated with Probe $1\left(10^{-5} \mathrm{M}\right)$ for $30 \mathrm{~min}$, (e) pretreated with LPS $\left(1 \mu \mathrm{g} \mathrm{mL}{ }^{-1}\right)$ for $6 \mathrm{~h}$, and further incubated with PMA $\left(1 \mu \mathrm{g} \mathrm{mL}^{-1}\right)$ for another 30 min after HeLa cells preincubation with Probe 1 for $30 \mathrm{~min}$, and (c and f) overlay of (a) with (b), (d) with (e), respectively, (g) the bars represent the fluorescence intensity of the corresponding cells. The provided images of live HeLa cells macrophage are representative ones ( $n=6$ fields of cells).

(Fig. 4b). The superposition of fluorescence and bright field images showed that the fluorescence signal located in the intracellular region, indicating the subcellular distribution of $\mathrm{NaClO}$ and good cell-membrane permeability of Probe 1. To further investigate whether the Probe 1 has an inhibitory effect on endogenous HOCl, HeLa cells were selected as a cell model and treated with phorbol myristate acetate (PMA) and lipopolysaccharide (LPS) to produce $\mathrm{HOCl}^{47}$ After stimulation with PMA and LPS in the presence of Probe $1\left(10^{-5} \mathrm{M}\right)$, bright green fluorescence was clearly observed to be quenched in HeLa cells (Fig. 5). These data indicate that the probe can be used as an indicator in the process of endogenous $\mathrm{HOCl}$ production in cells.

\section{Conclusions}

In summary, a novel thioether responsive fluorescent probe based on ICT mechanism was constructed for the detection of HOCl. At the same time, since it has high selectivity, fast response speed $(<2 \mathrm{~min})$, large Stokes shift $(120 \mathrm{~nm})$, high fluorescence quantum yield $(\Phi=0.93)$, low detection limit $(0.237 \mu \mathrm{M})$ and visible colour change, the probe has good potential application. In addition, fluorescence confocal imaging experiments on HeLa cell model showed that Probe 1 was feasible in detecting endogenous and exogenous hypochlorous acid.

\section{Conflicts of interest}

There are no conflicts to declare.

\section{Acknowledgements}

This work was supported by the National Natural Science Foundation of China (No. 21606147 and 21305079), the Academy of Science and Technology Project of Shandong Academy of Medical Sciences (No. 2017-55, 2018-19), Key Projects of Industrial Science and Technology Plan in Qiannan Prefecture (2017) 11, Project of the Haixi Science and Technology Bureau of Qinghai Province 2017-Q4. 


\section{Notes and references}

1 J. M. Zgliczyński, T. Stelmaszyńska, W. Ostrowiski, J. Naskalski and J. Sznajd, Eur. J. Biochem., 2010, 4, 540-547.

2 J. Shepherd, S. A. Hilderbrand, P. Waterman, J. W. Heinecke, R. Weissleder and P. Libby, Chem. Biol., 2007, 14, 1221-1231.

3 C. Liu, Q. Wang, X. Jiao, H. Yao, S. He, L. Zhao and X. Zeng, Dyes Pigm., 2019, 160, 989-994.

4 L.-J. Zhang, X. Zhao, D. Yang, Z.-Z. Jia, X. Han, L.-Q. Sun, L.-L. Yu, J.-T. Liu, X.-D. He, J.-Y. Miao and B.-X. Zhao, Sens. Actuators, B, 2018, 276, 8-12.

5 H. Guo, Y. Jing, X. Yuan, S. Ji, J. Zhao, X. Li and Y. Kan, Org. Biomol. Chem., 2011, 9, 3844-3853.

6 S. J. Klebanoff, J. Leukocyte Biol., 2005, 77, 598-625.

7 M. Sun, H. Yu, H. Zhu, F. Ma, S. Zhang, D. Huang and S. Wang, Anal. Chem., 2014, 86, 671-677.

8 J. E. Harrison and J. Schultz, J. Biol. Chem., 1976, 251, 13711374.

9 D. Pattison and M. Davies, Chem. Res. Toxicol., 2012, 14, 1453-1464.

10 M. Benhar, D. Engelberg and A. Levitzki, EMBO Rep., 2002, 3, 420-425.

11 Y. R. Zhang, X. P. Chen, J. Shao, J. Y. Zhang, Q. Yuan, J. Y. Miao and B. X. Zhao, Chem. Commun., 2014, 50, 14241-14244.

12 K. Dou, G. Chen, F. Yu, Z. Sun, G. Li, X. Zhao, L. Chen and J. You, J. Mater. Chem. B, 2017, 5, 8389-8398.

13 D. Zheng, X. Qiu, C. Liu, X. Jiao, S. He, L. Zhao and X. Zeng, New J. Chem., 2018, 42, 5135-5141.

14 C. Tang, Y. Gao, T. Liu, Y. Lin, X. Zhang, C. Zhang, X. Li, T. Zhang, L. Du and M. Li, Org. Biomol. Chem., 2018, 16, 645-651.

15 H. Ma, B. Song, Y. Wang, D. Cong, Y. Jiang and J. Yuan, Chem. Sci., 2016, 8, 150-159.

16 O. Lupan, L. Chow, T. Pauporté, L. K. Ono, B. R. Cuenya and G. Chai, Sens. Actuators, B, 2012, 173, 772-780.

17 I. G. Casella and M. Gatta, J. Agric. Food Chem., 2002, 50, 2328.

18 S. Iguchi, Y. Miseki and K. Sayama, Sustainable Energy Fuels, 2018, 2, 155-162.

19 X. Liang, L. Zhang, X. Xu, D. Qiao, T. Shen, Z. Yin and L. Shang, ChemistrySelect, 2019, 4, 1330-1336.

20 M. Lin, J. Huang, F. Zeng and S. Wu, Chem.-Asian J., 2019, 14, 802-808.

21 M. Ren, B. Deng, K. Zhou, X. Kong, J.-Y. Wang and W. Lin, Anal. Chem., 2017, 89, 552-555.

22 W. Wu, J. Li, L. Chen, Z. Ma, W. Zhang, Z. Liu, Y. Cheng, L. Du and M. Li, Anal. Chem., 2014, 86, 9800-9806.
23 Q. Xu, K.-A. Lee, S. Lee, K. M. Lee, W.-J. Lee and J. Yoon, J. Am. Chem. Soc., 2013, 135, 9944-9949.

24 X. Li, Q. Liu, S. Ye, S. Wang, K. Li, G. Lv, Y. Peng, L. Qiu and J. Lin, Chem. Biol. Drug Des., 2019, 80, 1-10.

25 M. J. Chang, J. H. Joo and M. H. Lee, Bull. Korean Chem. Soc., 2019, 40, 539-543.

26 L. Zang, C. Liang, W. Ying, W. Bu, H. Sun and S. Jiang, Sens. Actuators, B, 2015, 211, 164-169.

27 Z. Hao, F. Jiangli, W. Jingyun, M. Huiying and P. Xiaojun, J. Am. Chem. Soc., 2014, 136, 12820-12823.

28 B. Zhang, X. Yang, R. Zhang, Y. Liu, X. Ren, M. Xian, Y. Ye and Y. Zhao, Anal. Chem., 2017, 89, 10384-10390.

29 Y.-R. Zhang, Z.-M. Zhao, L. Su, J.-Y. Miao and B.-X. Zhao, RSC Adv., 2016, 6, 17059-17063.

30 K. Xiong, F. Huo, C. Yin, Y. Chu, Y. Yang, J. Chao and A. Zheng, Sens. Actuators, B, 2016, 224, 307-314.

31 S. Kenmoku, Y. Urano, H. Kojima and T. Nagano, J. Am. Chem. Soc., 2007, 129, 7313-7318.

32 Y. Koide, Y. Urano, K. Hanaoka, T. Terai and T. Nagano, J. Am. Chem. Soc., 2011, 133, 5680-5682.

33 P. Venkatesan and S.-P. Wu, Analyst, 2015, 140, 1349-1355.

34 B. Chen, H. Fu, Y. Lv, X. Li and Y. Han, Tetrahedron Lett., 2018, 59, 1116-1120.

35 S.-R. Liu and S.-P. Wu, Org. Lett., 2013, 15, 878-881.

36 W. Feng, Q.-L. Qiao, S. Leng, L. Miao, W.-T. Yin, L.-Q. Wang and Z.-C. Xu, Chin. Chem. Lett., 2016, 27, 1554-1558.

37 Q. Duan, P. Jia, Z. Zhuang, C. Liu, X. Zhang, Z. Wang, W. Sheng, Z. Li, H. Zhu, B. Zhu and X. Zhang, Anal. Chem., 2019, 91, 2163-2168.

38 S. Mingtai, Y. Huan, Z. Houjuan, M. Fang, Z. Shan, H. Dejian and W. Suhua, Anal. Chem., 2014, 86, 671-677.

39 M. Ren, Z. Li, B. Deng, L. Wang and W. Lin, Anal. Chem., 2019, 91, 2932-2938.

40 R. Joshi, O. R. Meitei, H. Kumar, M. Jadhao and S. K. Ghosh, J. Phys. Chem. A, 2016, 120, 1000-1011.

41 J. Liu and Z. Yin, Talanta, 2019, 196, 352-356.

42 N. I. Georgiev, P. V. Krasteva and V. B. Bojinov, J. Lumin., 2019, 212, 271-278.

43 C. Duan, M. Won, P. Verwilst, J. Xu, H. S. Kim, L. Zeng and J. S. Kim, Anal. Chem., 2019, 91, 4172-4178.

44 B. Deng, M. Ren, X. Kong, Z. Kai and W. Lin, Sens. Actuators, $B$, 2017, 255, 963-969.

45 M. Vedamalai, D. Kedaria, R. Vasita and I. Gupta, Sens. Actuators, B, 2018, 263, 137-142.

46 Y. Yang, F. Huo, C. Yin, M. Xu, Y. Hu, J. Chao, Y. Zhang, T. E. Glass and J. Yoon, J. Mater. Chem. B, 2016, 4, 5101-5104.

47 X. Han, C. Tian, J. Jiang, M. S. Yuan, S. W. Chen, J. Xu, T. Li and J. Wang, Talanta, 2018, 186, 65-72. 